\title{
Article \\ Creating Demand and Creating Knowledge Communities: Myanmar/Burmese Buddhist Women, Monk Teachers, and the Shaping of Transnational Teachings
}

\author{
Rachelle Saruya (D)
}

check for

updates

Citation: Saruya, Rachelle. 2022.

Creating Demand and Creating Knowledge Communities:

Myanmar/Burmese Buddhist

Women, Monk Teachers, and the

Shaping of Transnational Teachings.

Religions 13: 98. https://doi.org/

10.3390/rel13020098

Academic Editor: Pascale

F. Engelmajer

Received: 11 March 2021

Accepted: 9 December 2021

Published: 20 January 2022

Publisher's Note: MDPI stays neutral with regard to jurisdictional claims in published maps and institutional affiliations.

Copyright: (C) 2022 by the author. Licensee MDPI, Basel, Switzerland. This article is an open access article distributed under the terms and conditions of the Creative Commons Attribution (CC BY) license (https:/ / creativecommons.org/licenses/by/ $4.0 /)$.
Department for the Study of Religion, University of Toronto, Toronto, ON M5R 2M8, Canada; rachelle.saruya@mail.utoronto.ca

\begin{abstract}
The importance of Abhidhamma (higher doctrine) in Myanmar Buddhist society is well known. However, it is only within the last century that this doctrine has become more accessible to the laity, and specifically to women devotees. Today, women make up the majority of monks' devotees in the country. Indeed, as this article argues, a major role in increasing the Abhidhamma's importance and visibility in Burmese society has been played by women. Although monks such as Ledi Sayadaw (1846-1923) reworked the teachings to make them more accessible to the laity, laywomen seem to have played an active role in creating a "demand" for learning the more difficult Buddhist teachings that were previously only available to monastic elites. It may be difficult to find individual female authors or references to women in texts written by monks during the earlier part of the colonial era, yet we can find examples of women displaying agency as part of larger groups. This fact complicates the notion of individual agency that is usually focused on in current research. During the colonial era, a considerable number of literate women were part of a "growing reading public," and I argue that Burmese laywomen created a "demand" for learning Buddhist doctrine, with monks then creating a "supply". My suspicions grew regarding women's "demand" for learning, from multi-sited ethnographic fieldwork carried out in Myanmar at a village monastery near Meiktila in 2014, and at a suburban house monastery in the San Francisco Bay Area during various visits beginning in 2010. I found that after observing the same teaching monk in both places that one woman student was responsible for creating these "knowledge communities" after creating a "demand" to learn the Abhidhamma. I was also able to learn how this monk's doctrinal content and pedagogical methods of his teaching practice had been impacted not only by the different teaching environments, but also by the female students at the two sites.
\end{abstract}

Keywords: Myanmar Buddhism; Burmese Buddhism; abhidhamma; Abhidhammatthasangaha; gender and Buddhism; Burmese diaspora; transnational teachings; Buddhist laywomen; Buddhist education; Buddhist laity

\section{Introduction}

The majority of Buddhist monks' devotees in Myanmar $^{1}$ are women. ${ }^{2}$ During the colonial period, the fear that Buddhist knowledge would disappear caused the laity, including women devotees, to become more active in organizing efforts to counter this (Braun 2013; Ikeya 2011; Jordt 2007; Turner 2014). Soon after the colonial power abolished the monarchy in 1885, the laity assumed supportive roles for monks that were once the monarchy's responsibility. Moreover, monks such as Ledi Sayadaw (1846-1923) reworked the teachings to make them more accessible to the laity (Braun 2013). This article argues that laywomen seem to have played an active role in creating a "demand" for learning the more difficult Buddhist teachings (the Abhidhamma) once only available to monastic elites. Although it may be difficult to find individual female authors or references to women in texts written by monks during the earlier part of the colonial period, we can find examples of women 
displaying agency as part of larger groups. This fact complicates the notion of individual agency that is usually focused on in current research (Starling 2018). During the colonial era, a considerable number of literate women were part of a "growing reading public" (Ikeya 2011, p. 59), and I argue, similarly to Jessica Starling's (2018) research on laywomen in the Japanese context, that Burmese laywomen created a "demand" for learning Buddhist doctrine, with monks then creating a "supply". This article examines how lay Buddhist "knowledge communities" form (Barth 2002; Jordt 2006), ${ }^{3}$ and how such communities expand as a result of more female participation in secular education, resistance against perceived threats, and global processes. My suspicions grew regarding women's "demand" for learning, from multi-sited ethnographic fieldwork conducted in Myanmar at a village monastery near Meiktila in 2014, and at a suburban house monastery in the San Francisco Bay Area during various visits beginning in 2010. I examined how Buddhist teachings and pedagogies have changed through time and space, as well as how they have been made accessible to the laity, in particular to women devotees. Observing the same monk teaching at both places helped me understand how one woman was responsible for the "demand" and creation of the Abhidhamma knowledge communities, and how the doctrinal content and pedagogical methods of this monk's teaching practice had been impacted not only by the different teaching environments, but also by the female students at the two sites.

In the following, I first look briefly at female education in Burma in the nineteenth and early twentieth centuries, and the steps taken at that time by Buddhists, afraid that they would lose their Buddhist scriptural knowledge, to protect themselves from this potential loss. This includes how the rise in print culture helped support the demand for learning Buddhist doctrine, and how this development made the teachings more accessible to a new audience, namely women laity, with laywomen playing an active role in learning these teachings. In addition, I provide the example of the "mass lay meditation movement," which has also been primarily promoted and observed by women. After this, I turn to the contemporary case study involving the two different places and audiences: a diasporic community in the San Francisco Bay Area, where most of the students are Chinese Burmese women, and a village located near Meiktila in Burma, where the teaching monk of the Bay Area community was born. In this village, most students are Bamar female farmers. Different pedagogical strategies are needed in these two locations, strategies that have been modified through processes of globalization. Moreover, information from laypersons in these two locations revealed how identities changed during stays abroad, which in turn influenced the development of these two knowledge communities.

\section{Fears of Decline in Doctrinal Knowledge, Yet a Growth of the Reading Public}

Although it is difficult to find examples regarding women's literacy and education before the colonial era, some lay girls may have received a basic education at monasteries up to a certain age. If lay girls and women were excluded from the advanced text-based education available to boys at monasteries, they would have had some informal Buddhist education through listening to monks' sermons. During King Mindon's reign (1853-1878) we can find educated nuns, such as Me Kin (1814-1882), who taught the ladies of the court. Her scholarly lineage is traceable to the many learned nuns today (See Kawanami 2013; Rawe Htun 2001). Burmese chronicles, such as the Sāsanavamsa, tell of how studying Pali grammar was "popular" amongst women and girls during the Bagan period (1044-1297) (See Bode 1909, p. 25; Paññasāmi and Bode 1897, p. 25; Tin Lwin 1961, p. 25). Inscriptions from this period describe a small percentage of women slaves who were literate, and there are inscriptions describing bhikkhuniss (fully ordained nuns) ${ }^{4}$ who were literate in Buddhist ritual knowledge (Than Tun 1956).

Starting in the eighteenth century and accelerating during colonial rule, Christian missionaries ran schools that were attended by an increasing number of girls and women (Ikeya 2011, pp. 31-32). The British colonial government, however, did not start showing interest in working on their own school projects until the $1860 \mathrm{~s}$ (ibid). Christian missionaries were anxious to teach girls with the hopes that they would later pass on the teachings of the 
Christian faith to their own children. Missionaries, who were the majority of respondents to a Christian Literature Society survey in 1914, claimed that Burmese women knew "'nothing else but Buddhism'; they agreed that Anglo-Christian education was the key solution to the problem of "uneducated' women in Burma" (p. 32). This view was based on the standard Anglo-Christian formal education for girls, which included how to be a good Christian homemaker (ibid). Jessica Harriden states that formal educational opportunities for lay girls and thilashin (Myanmar Buddhist nuns) ${ }^{5}$ were "limited in pre-colonial Burma," since "most teachers (who were predominately monks) did not prioritize female education" (Harriden 2012). It was only in the colonial era that "female education in general became more acceptable" (ibid), with "significant growth in female education and literacy" starting in the 1910s (Ikeya 2011, p. 54).

Many Buddhists felt uneasy about girls receiving a colonial government and/or missionary education. This was connected to their fears of Buddhism declining in Burma, fears supported by the prediction in the Pali Canon that Buddhist knowledge would wane. In the commentary on the Anguttara Nikāya, ${ }^{6}$ it states that Buddhism will decline over time; therefore, the knowledge of the scriptures will eventually disappear. The first text to disappear would be the Patthāna, the last volume in the Abhidhamma, a text considered the most difficult to understand. In Sagaing, Myanmar, where I have done research on Buddhist nuns, a nun explained to me that "the Patthāna is the first to go because of its very deep nature, and people do not want to use their brains"'(Saruya 2020). ${ }^{7}$ Widespread efforts to prevent its loss can be seen in the mass Patthāna recitation festivals and in the common visual representation of the twenty-four conditions that are the basis for the text's doctrine. ${ }^{8}$ Added to these prophecies was the real concern in the 1800 s, and also felt today, that an education that focused on secular subjects would result in the neglect of traditional Buddhist forms of knowledge and the transmission of Buddhist values, which might also weaken laywomen's support for the sangha. However, the rise in a "growing reading public" and a flourishing print culture, ultimately increased the accessibility of Buddhist teachings.

\section{Creating a Supply with New Technologies and Pedagogical Methods}

In the 1800s, the introduction of the printing press in Burma led Buddhist monks to take hold of new opportunities to spread Buddhist teachings (Ikeya 2011, p. 39). The printing press would allow them to easily produce Buddhist texts and to gain lay readers of print publications as a new audience:

The rise of Burmese-language newspapers and Buddhist journals as well as a sharp increase in the number of Buddhist books and tracts allowed for the rapid spread of ideas between villages and towns. Such media helped to create a sense of collective endeavor among Burmese Buddhists. (Turner 2014, p. 18)

The rise of print culture also gave women more access to scriptural knowledge. Moreover, improvements in transportation infrastructures helped shape knowledge communities by enabling more people to gather and listen to the sermons of prominent monks (Turner 2014, p. 41). One such monk was Ledi Sayadaw. In 1904, he published the Paramatthasamkhip ("Summary of the Ultimates"), a poem he had written based on the Abhidhammatthasangaha ("Compendium of the Abhidhamma"). The Abhidhammatthasangaha, a text thought to be written by a Sri Lankan monk sometime between the tenth and twelfth centuries, is a summary of the Abhidhamma proper. It is used as a primer for Myanmar monks and nuns as their first introduction to the Abhidhamma. The intention behind Ledi Sayadaw's publication was for his poem to be memorized by the laity to help spread these difficult teachings. For this purpose, he also formed the Paramatthasamkhip groups that consisted primarily of laywomen (Turner 2014, p. 42).

According to Erik Braun, Ledi Sayadaw "advocated, in response to the declining political and educational roles of the sangha, a new vision of modern Burmese Buddhism that placed utmost importance on the participation of the entire laity, not just the monastic 
elite or men, in the preservation of the Buddha's teachings" (Braun 2013, p. 64). ${ }^{9}$ Braun further mentions that:

He [Ledi Sayadaw] preached widely; he published numerous books, poems, articles, and other works; and he founded many social groups in various villages, towns, and cities to harness the collective energy of laypeople. (ibid, p. 78)

As Braun describes, by creating a demand for texts and instruction among the laity, Ledi Sayadaw was largely responsible for empowering the laity. Yet, Braun also notes that after the monarchy was abolished by the British, there was a united drive among the laity to support and maintain Buddhism. As he writes,

[Ledi Sayadaw's] efforts were stoked by lay requests and interactions that reflected a preexisting drive among the laity to act collectively. Indeed, most social organizations of the time were lay-founded, lay-organized, and lay-run. This initiative among the laity reminds us that they were not simply a passive and inchoate mass waiting for direction, but active agents in expressing the need for innovative responses to the challenges to Burmese Buddhism. (p. 97)

Braun further explains that commentaries were often created due to an "external request". An example of this can be seen in a passage at the beginning of Ledi Sayadaw's Paramatthadīpanī:

In this world are found many commentaries on the Abhidhammatthasangaha, explained by scholars of old. But those whose minds wish for the essential meaning do not gain satisfaction from these [commentaries]. Having approached me, they asked for an explanation of ultimate reality. (pp. 50-51, as cited and translated by Braun)

Ledi Sayadaw "never specifies" who requested this explanation, but Braun suggests that it may have been his students in Monywa, where he was teaching at the time he wrote the text. Ledi Sayadaw also mentions in his auto-commentary a lay request that resulted in the writing of his poem, the Paramatthasamkhip:

Having been asked to provide a means for people to master easily all nine chapters [of the Sangaha] I will speak a memorization-aid poem [sam pok'] which can be quickly mastered by women, men, students, and children, if they strive for three to four months. (p. 104, as cited and translated by Braun)

What is revealing about the author's intentions is the reference to women, who appear first in his list of potential audience members (p. 104). Moreover, in a letter to the British Pali scholar Caroline Rhys Davids, Ledi Sayadaw described his text as something "even girls can learn easily in four or five months," a further indicator of his intentions behind writing the text (p. 105, as cited by Braun). ${ }^{10}$

The poem gives definitions of Pali words together with some Burmese glosses, but like the original Abhidhammatthasangaha, the poem is very difficult to understand without an oral or written commentary. The Paramatthasamkhip groups that were established may have been used for this purpose. As described by Alicia Turner, these groups were mainly filled with young women, who memorized the poem and learned its meaning, whereupon they were tested by monks. As Turner writes, "these examinations proposed an inversion of the fundamental monastic, gendered, and aged hierarchies of Burmese society". (Turner 2014, pp. 41-43).

For the laity, memorizing the Paramatthasamkhip may have been easier than memorizing the original Pali of the Abhidhammatthasangaha, which is memorized by monastics. The Paramatthasamkhip uses a poetic formula called thanbauk (sam pok) that was popular at that time. Thanbauk poems have three lines in each verse with a syllabic rhyming method in a 4-3-2 sequence. In the Paramatthasamkhip these sequences sometimes vary, not always following the formula's rules, but one example that does follow this sequence rule is in the first verse: 
co thvat bhunh lhyam (to the Buddha) I tayāh moan (to the Dhamma) I samgham (to the Sangha) namāmi (I bow) $\| .{ }^{11}$

The underlined words contain the rhyming syllable, with a 4-3-2 sequence in the three lines. Often the ending syllable of each verse also rhymes with the rest of the verses in each section. In some verses, words have been shortened to one or two syllables to facilitate memorization. For instance, the Pali word kusala (wholesome) is shortened to just $k u$ and akusala (unwholesome) to $a k u$. This is common in mnemonic pedagogical practices for monastics in Myanmar, and most likely originated in this context, but has also been deployed in secular education and in fields such as astrology. ${ }^{12}$

The Paramatthasamkhip was not a direct translation of the Abhidhammatthasangaha, but a "'retranslation' that refocused Burmese Buddhism on lay life" (Braun 2013, p. 116). As Braun writes, "to learn at least key Pali terms and to have a sense of 'reading' Pali allowed a student of the Summary, at the high moment of British colonialism in Burma, to assert his or her identity as Buddhist" (p. 109). Again, learning these texts contributed to the Burmese Buddhist identity and resistance to the colonial government.

Although Ledi Sayadaw does not specify exactly who in the laity requested the poem's composition, the active role taken by the laity would have certainly included women. Increasing numbers of literate women were part of Burma's "growing reading public," enabling them to influence monks, not only as devotees but also as students.

\section{Rise of and Resistance in Other Women's Knowledge Communities}

Complementary to the Abhidhamma, Ledi Sayadaw, as well as other monks, also taught meditation to the laity. This eventually turned into the "mass lay meditation movement" (Braun 2013; Jordt 2007) in which today vipassanā (insight) meditation centers can be seen all over the world. Mahasi Sayadaw (1904-1982) became one of the most famous meditation teachers for the laity, and is credited for the strengthening of this movement. His meditation method and meditation center, in Yangon, are both still extremely popular even up to this day.

Ingrid Jordt describes the groups of laywomen participating in meditation and taking active roles in supporting the Mahasi Sayadaw meditation center in Yangon. Having conducted research there in the 1990s, she noted that women outnumbered men five to one (Jordt 2007, p. 37). Monks at the center explained that there were two reasons why more women meditated than men. The first reason being that women were more likely to suffer due to biological processes, such as childbirth. Consequently, they were eager to leave the cycle of samsāra, which can only be achieved through insight meditation. The second reason being that women had greater concentration abilities than men, which is needed for "successful meditation" (Jordt 2005, p. 52). Other factors may have also contributed to the rise in women practitioners. These factors included the possibility for women to stay at such centers as laypersons, only renouncing secular life temporarily and not having to become a full renunciate, and that the government began to support women in various aspects of life, including meditation (Jordt 2007, p. 161). "Dāna cliques," or "groups of lay donors [who] share in each others' merit-making events" at the meditation center, were also often comprised of women, with the biggest donors being women jewelers (Jordt 2007, pp. 106-8). Donating large sums of money to the center not only increased the status of these "big donors" in the society at large, but also as part of Buddhist soteriological concepts in which collecting merit ${ }^{13}$ leads to a better rebirth.

Although Burmese Buddhists resisted the colonial government by studying Buddhist texts and maintaining Buddhist practices, Jordt argues that the women in Buddhist meditation centers were resisting the Burmese regime, which at the time of her research was a military government bearing the official name State Law and Order Restoration Council (SLORC). Even though those in the regime displayed acts of dāna (giving) to the sangha, these acts were met with a suspicion of sincerity. By coming together and forming such meditation circles, women built an internal and hidden resistance to the regime, despite or in addition to deeper soteriological goals. 
Where public space is suppressed and controlled by a repressive regime, Burmese Buddhists claim control over the private space of their intention ${ }^{14}$ in pursuit of creating better life circumstances. This is accomplished through the widespread practices of meditation. From this place, I argue, people can challenge the government's sincerity in its sāsana-supporting actions while simultaneously exerting a sort of pressure on it. The overall effect is that a seemingly very private and individualistic practice, meditation, conceived as acting on one's own psychophysical processes, becomes a fulcrum of action in the social and political world. (Jordt 2007, p. 157)

Yet, such preoccupation with resistance in current scholarship on Burma has led me to question whether the women themselves viewed such learning and practice as resistance to the social conditions at hand, or if these descriptions were more the analysis of the observers (researchers). Laywomen's reasons for learning the Buddhist teachings during the colonial period may be difficult to find, and the local conditions and time periods may result in various answers, but I questioned the female students of Abhidhamma in today's knowledge communities about why they were learning, and specifically why more women were learning than men. I found that their answers did not correspond to any kind of resistance (that I could gather). Resistance that is not clearly marked as such, for example, the clear resistance to the current military regime in Myanmar, is perhaps more overt than the kind of resistance displayed by silent meditators. The women may not be able to articulate such reasons, or it may be that they do not view their actions as such, but asking the women themselves and the answers they give may need us to reevaluate what is important to the subjects themselves, and to include these answers in our research.

\section{The Creation of Abhidhamma Knowledge Communities in the Diaspora}

Most Burmese in the San Francisco Bay Area are Chinese Burmese, with the biggest populations residing in Fremont, Daly City, and the Sunset District of San Francisco. ${ }^{15}$ Joseph Cheah (2011) has shown that Burmese Buddhist monasteries are places where the Burmese diaspora are able to practice what Cheah calls "Burmeseness," with Burmese Buddhist religious and social practices functioning as means for resisting assimilation (p. 112). Cheah found that after immigrating to the United States, many of the Burmese saw themselves as middle or upper-class. I also found that many of the Abhidhamma students I interviewed in my research were medical doctors or otherwise highly educated, which corresponds to Cheah's data.

Although the majority of the Burmese laity in the San Francisco Bay Area are Chinese Burmese, most monks are Bamar, the majority ethnic group in Burma. Only one monk is from the Rakhine/Arakanese ethnic group. At the time this article was written, there were approximately twenty monks at thirteen monasteries. Although some lay members of Burmese monasteries in the Bay Area also have connections to Chinese Mahayana temples, they are active in taking care of and supporting Burmese monks and the local monasteries. I asked Ashin Garudhamma, the teaching monk upon whom much of the research for this article is focused, about the Chinese Burmese community in the United States and why he thought they were studying the Abhidhamma. He replied that for many Chinese Burmese, at the time they still lived in Burma they felt more "Chinese," often only attending Chinese Mahayana temples. They did not actively learn Theravada Buddhism, converse with Burmese monks, or attend Theravada monasteries. Nevertheless, when they arrived in the United States, many did not fit into the Chinese communities in the Bay Area, which are quite diverse. Members hail not only from Taiwan and mainland China, but also include Chinese Americans with a longer history in the country. Chinese Burmese in the United States thus sometimes feel more Burmese than Chinese. Ashin Garudhamma mentioned that even though the Chinese Burmese can easily attend a Mahayana temple in the Bay Area, they miss seeing things specifically Burmese, such as Burmese Theravada pongyis (monks). ${ }^{16}$ A laywoman, Daw Hla Hla, told me: "We are Chinese, we were not that close to the monks [in Burma]; here we have more of a chance. In Burma, there were too many 
monasteries, it was too overwhelming". ${ }^{17}$ Indeed, it is common human behavior to be disinterested when there is too much of something, but to be more interested in that same thing in a different context when there is less of it. It is thus possible that learning Buddhist teachings is not necessarily an act of resistance for the Chinese Burmese in the Bay Area, but represents rather their embracing a part of Burmese society that they could not fully embrace in Burma, or that they had become more interested in learning about now that they were abroad. ${ }^{18}$

Tamara Ho (2008) examined the active role that women played in bringing monks to the United States, and the informal power that these "female-centered networks" have in upholding and propagating the Dhamma (p. 184). Regarding women's agency, she writes that "although Burmese American women do not apparently question the hierarchy of gender in Burmese Buddhism, they find an agency and important roles in community building and networking through the temple" (p. 193). She further explains that "their deferral of self then becomes part and parcel of the sense of agency they gain as nonegoistic Buddhists" (p. 194). Although women come together through such groups and networks in both Burma and the United States, in the course of my research I gained the impression that it had been women who had created a "demand" to learn the Abhidhamma. This impression was formed during conversations with students in the Bay Area regarding the teachings of Ashin Garudhamma. I was told by Daw A that the reason Ashin Garudhamma began teaching the Abhidhamma was because she asked him to instruct her. She had attended a few lectures when the Abhidhamma teacher Dr. Mehm Tin Mon had visited the area, but in his lectures he did not discuss the vithi, the cognitive process. Since she was curious to learn more about this subject, she asked Ashin Garudhamma, who agreed to teach her. Her sister, Daw Hla Hla, was also interested in the same subject. As she told me,

at that time there was a Burmese teacher, Dr. Mehm Tin Mon. He taught the Abhidhamma just in ten days, but we couldn't understand it because it was too fast, and there was also a lot of Pali. At that time, we heard about the zaw [Pali: javana]. We had never heard about that in Burma, so we were curious. ${ }^{19}$

Here, Daw Hla Hla is referring to the part of the mind process in which kamma (karma) is produced. Javana means "running swiftly," and according to Bhikkhu Bodhi, "the javana stage is the most important from an ethical standpoint, for it is at this point that wholesome or unwholesome cittas [consciousness] originate". (Anuruddha and Bodhi 2000, p. 124) ${ }^{20}$

When Daw A asked Ashin Garudhamma to teach her, he had no experience teaching the laity, only monks. It, thus, took him several years of using various methods to find what worked when teaching lay students. He began with one student, with then others joining, the majority being women. Here, we see the side of demand placing women in an active role, with the monk teacher producing the supply.

Ashin Garudhamma began teaching by using the books of Dr. Mehm Tin Mon, since the latter was a lay teacher who taught members of the laity the Abhidhamma. However, he then turned to Ledi Sayadaw's poem, also giving each of his students a copy of Mingun Tipitaka Sayadaw's book on the poem thereon. Yet, he also found the poem unsatisfactory, since he believed it required his students to understand a language that in current times was no longer popular or understood as may have been the case in the colonial era. For instance, regarding the actual words, the word used for the Buddha above is no longer a word commonly used in Burmese. Ashin Garudhamma also decided that it was better to teach the relationships between the four ultimate truths: citta (consciousness), cetasika (mental factors), rüpa (matter), and nibbāna. Furthermore, he does not teach the Abhidhammatthasangaha's chapters in numerical order. For example, he first teaches chapter one on consciousness, then the second chapter on mental factors, then the sixth chapter on matter, and after, the fourth chapter on the mind process. ${ }^{21}$ Monastics emphasize memorization; Ledi Sayadaw also focused first on the laity memorizing his poem, followed probably by various ways of explaining what it meant. Ashin Garudhamma focuses on the Abhidhamma's meaning. It is easier for younger monastics or laity to begin studies with memorization, yet for older adults with limited time, understanding the meaning is 
more important than memorization. He also focuses on practice with vipassana and samatha meditation rather than what other teachers might prioritize in Myanmar; studying for the prestigious Abhidhamma examinations that the laity can take. ${ }^{22}$ Through the years, Ashin Garudhamma has written and collected his own material for his lectures, including lecture slides, explanatory texts, charts, as well as quotes and teachings from well-known monks. ${ }^{23}$

The in-person classes taught by Ashin Garudhamma that I took part in, had one hour of Abhidhamma, followed by a break that included thirty minutes of meditation. A few of the women in the class then warmed up food for a dinner that was shared by everyone. This was followed by an hour of studying specifically the Pațhāna. Whether in-person or on Zoom, time was allowed at the end of each class for questions. In the first few classes, the students asked many questions, but over time fewer of them came up. This was likely due to the teachings increasing in complexity, resulting in students having a difficult time forming questions. Initially, questions were often related to the students' background or life experiences. For instance, those who were doctors were curious about the role they should play in end-of-life care. Euthanasia of animals was also a topic of debate. As the number of questions became fewer, so did the number of students. At the beginning of the Zoom lesson series, there were approximately one hundred students, but after about seven months, this had dropped to fifty. One man who attended the in-person classes told me that if he missed a class, it was hard to catch up. He found it helpful that the lectures were recorded on YouTube. He also told me that he started learning Abhidhamma on recommendation from his sisters, who are also students.

Ashin Garudhamma mentioned that when visiting monks gave lectures to his students, it was often the case that these monks had never taught a lay audience before. His students usually understood little of what the visiting monk discussed. Regarding the differences between monastic and secular learning, he told me that "secular learning at first does not go into detail, in contrast to monastic learning, which does start off in great detail. Consequently, when a monk gives a sermon, he may speak in such detail that a layperson has difficulty understanding". He explained that when he started teaching this was also what happened, and that teaching monastics and teaching the laity are two different audiences with different pedagogical needs. ${ }^{24}$

\section{Shifting Gender in Transnational Settings}

As mentioned above, many Chinese Burmese laypersons who actively participate in Theravada monasteries in the United States had not done so in Burma. A further point of discussion is how gender roles have shifted in the two places. These shifts may have also contributed to laywomen feeling more comfortable to ask monks about Buddhist doctrine. A few women mentioned to me that monks were more accessible in the United States than in Burma. In Burma, despite there being many monks, because of a culture of reverence towards monks, these women felt uncomfortable asking them questions. According to Daw Hla Hla:

Here it is easy, over there monks are superior, right? We cannot ask questions, the lady over there cannot be that close to the monks, we stay far away from them. Here it is okay, we can ask questions. It is okay because of the American way. I like that. ${ }^{25}$

When conducting group interviews in the Burmese village, I noticed the ways in which the decorum of the laity was different from that in the United States. They were very reverential in front of monks, and often remained quiet when I asked them questions. I was surprised when Ashin Garudhamma's cousin, Ma Aye Myint, who I knew as someone who never shied away from speaking, stayed silent in front of him. ${ }^{26}$ When I asked her about her silence in a later interview she said it was because of sila (morality) that she pays respect to the sangha, because of the monk's morality. ${ }^{27}$ Yet, I did witness the only nun in the audience asking questions after the lecture was over. It may be that a nun would have more experience conversing with monks, and/or feel it is more appropriate for a 
female monastic to be able to do so. Women talking to monks about Buddhist teachings thus seems dependent on the situation and the actors involved. From my observations, in the Bay Area, many women studying Abhidhamma were older and took on a more motherly role. In fact, a couple women devotees, who were former students, are medaws. A medaw is an honorific title used for the mother of a monk, but can be used not only for the biological mother, but also for women who have become honorary mothers due to sponsoring an ordination, or in Ashin Garudhamma's case, repeated or renewed ordination (Pali: punopasampadā). ${ }^{28}$ Daw Yan Po, a laywoman who had arrived in the United States in 2012 and attended Abhidhamma classes in the Bay Area a few years earlier with her daughter, told me about her experiences of studying Abhidhamma in Myanmar and in the United States. She commented that women who study Abhidhamma in Yangon tended to be younger, whereas in the Bay Area the students were older. ${ }^{29}$ Thus, in the United States it seems that women have become more emboldened to ask questions based on the different styles of decorum and the age of participants.

There are also differences between the two countries regarding men that should not go unmentioned. More men attended the Abhidhamma classes in the United States than in Burma. This is similar in Thailand: Jiemin Bao (2008) described that men's participation at Thai temples was higher in the United States than in Thailand. In Thailand, it is mostly women who attend temples. Bao believes that the Thai men she studied were attempting to fit into American middle-class behavior. An example of this can be seen in her examination of promiscuity in Thai men and the influence the different contexts have on concepts of masculinity. In Thailand, masculinity is often conflated with men visiting brothels, whereas in the American middle-class context, Thai men at least appeared to be faithful to their wives, ostensibly due to American Christian influences. I cannot comment on notions of masculinity of Burmese men in Burma or America, but it is conspicuous that more men attend monasteries in the United States. Buddhism classes have not been a focus of Bao's research; it would be interesting to know if in the Thai context, more men would also attend classes in the United States.

Yet, in the Burmese context I examined, some of the men did not have wives or were divorced. Men being accompanied by their wives may be common American middle-class decorum, I nonetheless found that the men also actively wanted to study the Abhidhamma. Men took charge of producing YouTube videos of the classes, and then later, during the coronavirus pandemic, of setting up Zoom lessons. Being in Silicon Valley, some of these students were employees at Google or other tech companies and had taught Ashin Garudhamma how to use some of the technology he later used in classes in the Bay Area and then in his native village in Myanmar. In the Zoom lessons it seemed that as many men participated as women, although not everyone used a camera and names can be misleading. The moderator in these Zoom lessons was a man who teaches Buddhist content in various other formats as well, such as Dhamma classes for Burmese American children, and organizes a group of monks who give instruction in meditation and other Buddhist teachings. Due to the pandemic, more men had a sudden increase in free time, and increased accessibility through online platforms like Zoom meant that learning the Abhidhamma and Pali from a distance could be easily undertaken without having to be physically present at a monastery.

\section{Teaching in a Village Knowledge Community}

There were other differences between the knowledge communities in the Myanmar village I visited and of those in the San Francisco Bay Area. With regard to the spaces that the classes were held in, the Abhidhamma and Pali classes in the Bay Area were held at a monastery in a suburban house, a common form for monasteries in the United States. In contrast, the Abhidhamma classes in Myanmar were held at one of the two village monasteries that were built as dedicated structures. The village monastery also had a large white pagoda that was donated by American donors. In Myanmar, most of the students in my study were women farmers. These women numbered around fifty and arrived every 
day at $6 \mathrm{pm}$ after their work was finished. Many had had formal education only through the fourth standard, which made reading during the lessons difficult for them. The handful of men who were present were Ashin Garudhamma's relatives. Ashin Garudhamma used the same technology he used in the United States, such as a computer with PowerPoint and a projector. Although such technology may be common in larger cities in Burma, such as Yangon or Mandalay, at this time in the village, in 2014, it was quite novel. Ashin Garudhamma's voice was projected over a loudspeaker so that the entire village could hear him, making the Abhidhamma accessible to those outside of the monastery. Using loudspeakers when teaching, preaching, or during recitation festivals, such as for the Pațthāna is very common in Myanmar. In the United States, Ashin Garudhamma also uses a sound system to amplify his voice, an influence from Myanmar, but with restrictions on noise levels in the United States, the volume must be lower. Burmese Buddhists believe that merely hearing the teachings will bring the listener merit, and thus those who were physically unable to attend the monastery could still listen in.

The beginning and end of each class was marked by the laity reciting devotional formulas in unison. The devotional recitations at the beginning were followed by the previous day's lessons, which were also in recitation form. The villagers are familiar with this way of learning and enjoy it. It also helps in the cases of women who are uncomfortable with their reading skills. The teaching style in the village was based on a style similar to preaching, at times with patterns of call and response. After repeated reciting of passages building on the previous day's lessons, the texts slowly became easier for the group to grasp. In the Bay Area, students are not interested in chanting. Therefore, this type of learning is used less.

\section{Why Do More Women Study Abhidhamma?}

In the village, when asking the women why they were studying Abhidhamma, one woman explained that it was due to hearing the Patthana during the recitation festivals and wanting to understand what the text meant. Another woman commented that after learning about the mind, she was able to use her knowledge to calm herself down during frustrating times, such as when her baby was crying, and thus she was able to actively apply the knowledge she had acquired. Most, however, explained that the reason they were learning Abhidhamma was to acquire merit. Various comments were made about why more women took part in the classes, such as some men were too busy drinking, had other responsibilities, or that women often had more merit to begin with. In both Myanmar and the Bay Area, many students stated that they had to take the classes repeatedly, and that by doing so the Abhidhamma would eventually become clearer.

The lay students in the Bay Area gave similar answers to those in the village. One woman said that she was learning the Abhidhamma because even though she was Buddhist, she did not really understand what the Abhidhamma was about. Another student commented that "we never study ourselves, where our mind is going, the process of the mind. Now, whatever I encounter it is ok, it has become easier to deal with certain people." Another student explained that there was nothing more important than the future life, and not wanting to go to hell. Learning the Abhidhamma then was a way to accumulate merit as a means to a better rebirth. When I asked why there were more women attending the classes in the Bay Area, I was also told that this was due to women having more merit and saddha, or faith, and that there are more female deities than male in the Buddhist cosmological realms. I believe that this example shows that the women in these communities have a nuanced understanding of a complex hierarchal gender system, whereby they place themselves above certain laymen. This complicates traditional understandings of gender in Theravada Buddhism. They did not make comments about any kind of resistance, but about improving their chances for a better rebirth. Daw Hla Hla had another reason for why she thought there were generally more women at the monasteries:

I think it is because women like to cook, so they offer food. We like to approach the monk to protect us, we want to follow them, offer to them, get good karma, 
men are stronger probably (laughing). They said that we women are lower than men, I cannot accept that at all ... Maybe a lot of women depend too much on the man, not me, not you. I think it should depend on the person, not the man or the woman.

Cooking for monks does allow chances to connect with them, and the gratitude that monks may associate with this is a reason for the monks to want to "return the gratitude" ${ }^{\prime 30}$ to the laity by teaching. This idea of "returning the gratitude," known in Burmese as kyezusat, has also been a focal point of the research I have done on Burmese nuns (Saruya 2020). Monks may feel a responsibility or duty to care and protect those that have helped them along the way. Teaching the Dhamma is also a way for the monk to acquire merit along with the laity who is listening to these teachings.

\section{Conclusions}

The only nun who was in the village at the time of the classes I visited said that she had traveled from a different village, and that it was rare for Abhidhamma to be taught in the area. The laity in the Bay Area also commented that there were no other Abhidhamma teachers currently in the region. One of the first Burmese Buddhist monks to reside in the United States, U Silananda, taught Abhidhamma to the laity; however, he passed away in 2005. ${ }^{31}$ It thus seems that more research needs to be done on the current prevalence of classes on Abhidhamma for the laity. Are classes usually conducted only in major cities such as Yangon and Mandalay? It may be the case that monks rarely return for extended periods to the villages where they were born, preferring bigger cities or monastic centers such as Sagaing. In her research on giving, Hiroko Kawanami mentions that in the past, monks used to return to their natal villages after receiving their monastic education. She writes that today, in contrast, "monks from rural communities may come back to perform ceremonial roles on important occasions and fulfill their sense of communal obligation, but they rarely stay there and return to their urban monasteries to further their monastic careers" (Kawanami 2020, p. 34). This is different from the time of Ledi Sayadaw, who, it has been reported, preached and taught throughout the country. Regarding one monk's comments on the differences between teaching people in rural areas versus urban centers, Jordt has written:

Rural people want to hear about the deva [celestial] realms and Jataka stories [tales of the lives of the Buddha] ... about how they will become rich if they donate or how they will be reborn in the deva realms if they keep their precepts and make offerings. They want their discourses to be long, to go deep into the night ... and they even fall asleep during the discourse. Alternatively, urban people want short discourses, 45 minutes long and they want it on the Abhidhamma [abstruse texts dealing with the description of consciousness, mental states and meditation practices]. (Jordt 2006, pp. 200-1)

Nonetheless, I found that villagers in Myanmar were eager and responsive to the Abhidhamma classes. It may be that there are few opportunities, again, of teaching monks residing in rural monasteries for three months at a time. Women laity were eager for this supply, even if the demand had been created overseas.

Through the years, some Myanmar Buddhists have reworked the texts to help various groups understand Buddhist doctrine. This is considered crucial for maintaining the transmission and survival of the sāsana. ${ }^{32}$ This was demonstrated in Ledi Sayadaw's texts. My contemporary case study also demonstrates how teaching must be adjusted to different audiences. In my research on nuns, I found that the use of Insein Sayadaw's ${ }^{33}$ texts were popular amongst monks and nuns at many monasteries and nunneries when studying for the monastic exams. As one nun informed me, "this newer generation does not understand like the older generation. Insein Sayadaw wrote this book with that in mind, according to the current life" (Saruya 2020). ${ }^{34}$ Yet, at one nunnery where I undertook research, some of the books the teachers and students were using were quite old. The nun teachers had 
most likely learned from these books as students and so were familiar with them. Whether the student nuns could understand the content fully was hard to determine. As Ashin Garudhamma himself has stated, it was only after becoming a teacher that he began to gain a deeper understanding of the Abhidhamma.

The knowledge communities I observed were far apart, with learners and eventual knowers that had very different backgrounds. By watching how they were taught by the same teacher, I was able to witness how he was influenced by his students, and how these influences manifested in the changing pedagogies and mediums. The "demand" was first created by a woman devotee and the "supply" of teachings then provided to her, this growing into larger knowledge communities spanning two countries, and with the Zoom classes, possibly even more. More attention should be given to the often "invisible" women who influence the conditions at hand, but are overlooked or subsumed under the monk teacher or author.

In addition, Ashin Garudhamma and Daw Yan Po had brought to my attention that currently the majority of Abhidhamma teachers in Myanmar for the laity are laywomen. Ashin Garudhamma believes that this is because it is women who desire to understand the teachings; they are the main devotees of monks. However, since monks are generally not trained to teach the laity, women have developed ways to fill this gap. A laywoman Dhamma teacher who was teaching at the International Theravada Buddhist Missionary University in Yangon explained to me that the teacher gender ratio at the University was about 50/50, half women and half men, and that most students were laywomen. ${ }^{35}$ Daw Yan Po said that she first started learning from a laywoman teacher in Yangon:

The monastery near my house had an abbot, but that abbot didn't like it when many people came to the monastery. After that abbot passed away, another abbot came. He liked to study, but he hadn't studied the Tipitaka [Pali Canon] completely. Later a layman asked him if they could hold an Abhidhamma class. The monk also wanted to learn Abhidhamma. A laywoman teacher came to that monastery and the abbot learned from the lady teacher. ${ }^{36}$

Here, is an example, albeit rare, of a monk learning Abhidhamma from a woman. Moreover, according to Daw Yan Po, it was a layman who asked for the Abhidhamma classes. Knowledge communities can form in various combinations and perhaps this scenario will become more common.

In my research on nuns, I considered the possibility of the duty of propagating the teachings falling fully to nuns in the future, since more nuns are passing difficult monastic examinations and the nun population is rising, whereas that of monks is falling. The knowledge communities involving the Abhidhamma, considered the most significant doctrine for understanding Buddhism, clearly reflects a shift in knowledge production within the women laity as well. The shift to more female students, which will most likely lead to an increase in the number of female teachers, may tilt the gender balance even further in the future.

Funding: This research received no external funding.

Acknowledgments: I would like to express my sincere gratitude to Christoph Emmrich, Cynthia Peck-Kubaczek, Ashin Nyanawara, Min M. Hlaing, Mu Mu Kin, and the two anonymous reviewers for their valuable comments and suggestions on previous drafts of this article. I am also thankful to those at the SEASGRAD conference at UC Riverside and the Tokyo Buddhist Discussion Group where I also received valuable feedback. In addition, many thanks to Carole Zhang and Pascale Engelmajer for their help and patience with this article. Finally, I am forever grateful to Ashin Garudhamma and his students in Kanmon and in the Bay Area, for without their help and kindness this research would not be possible. Any mistakes are my own.

Conflicts of Interest: The author declares no conflict of interest. 


\section{Notes}

I use the names Myanmar and Burma interchangeably.

Most Burmese words are given in the popular transcription (without diacritics) and/or the simplified Lammerts and Griffiths transliteration system, and occasionally with the Pali transliteration. I do not use diacritics on words such as Pali, Theravada, Mahayana, etc., as they are commonly employed in English without.

3 Barth's concept of "knowledge communities" has "three interconnected faces of knowledge: a substantive corpus of assertions, a range of media representation, and social organization". (Barth 2002, p. 3).

4 There is debate regarding whether these nuns were actual bhikkhuniss, as some believe the bhikkhunī lineage died out in Burma much earlier than the Bagan period (see Rawe Htun 2001).

5 Kawanami (2013) describes how thilashin have had to fight for their education, sometimes listening to monks teaching while in the back of the room, hidden from view. They were not supported at first in the same ways that laywomen were with secular education. Often nuns would seek out former monks to learn from.

6 More specifically, the Dutiyapamādādivaggavaṇnanā (commentary on the Dutiyapamāāadivaggo in the Ekakanipātapāli $i$ ).

7 Interview, Ayemyo Chaung nun (24 August 2019), Sagaing, Myanmar.

8 Translated as "Conditional Relations" (Nārada 1969). The Pațhāna text is five volumes in length; at recitation festivals it takes aproximately four to five days to recite all volumes.

9 There were also other monks and laypersons who contributed at this time to the lay knowledge communities in Burma, but they have not been the focus of a study as in-depth as that of Braun on Ledi Sayadaw.

10 Ledi Sayadaw's student U Maung Gyi (Ledi Pandita Sayadaw) noted in his introduction in the Paramatthasamkhip Lak Cvai that the Paramatthasamkhip was written for everyone: monks, men, women, and children, thus not placing such a strong emphasis on women (Ledi Sayadaw n.d., p. 1). Ledi Sayadaw ([1904] 1986). Simplified Lammerts and Griffiths transliteration system.

I thank Ashin Garudhamma for pointing this out to me.

Merit is usually thought of in Myanmar as "kutho", originating from the Pali kusala (wholesome), and is in reference to wholesome kamma. This definition is in contrast to puñña, which is often how merit is expressed in other Buddhist contexts (Kawanami 2020). Here, intention means the mental factor cetanā (see note 20 in this article for more).

Many Chinese Burmese in the Bay Area did not leave Burma as refugees, which is more common for Burmese in other parts of the United States, but on skilled worker visas. Not leaving as refugees, however, did not mean that their lives were comfortable in Burma, since many Chinese Burmese left due to anti-Chinese sentiment. The largest wave of Chinese Burmese immigrants left Burma after the 1967 anti-Chinese riots (Cheah 2011, p. 116). Phone conversation (18 January 2021).

Interview (11 April 2021), internet communication.

Cheah argues that the Chinese Burmese had to "Burmanize" in Burma by changing their Chinese names to Burmese ones and suppressing their Chinese identities. In the United States, however, Chinese Burmese often use their Chinese names on written forms. In contrast, Jayde Roberts (2016) has demonstrated how the Chinese Burmese were able to create and maintain Chinese spaces in Yangon by means of Chinese Mahayana temples and traditions, such as the lion dances. She also notes that "those people who sought out the security of a Chinese space [abroad] felt like outcasts. Stories of their suffering quickly traveled back to Burma, making the Sino-Burmese in Rangoon realize that, despite the numerous challenges, Burma was their only home" (p. 141). As she explains, the Chinese Burmese are perpetually in an "in-between state". "They remain perpetually other, not only in their adopted home of Rangoon but also among other Chinese populations" (ibid). Interview (11 April 2021), internet communication.

It is specifically in the mental factor cetana (commonly translated as volition or intention) during the javana stage where kamma is produced. Intention was mentioned in the above quote in this article from Jordt (p. 6) in which she is referring to this phenomena. In addition, Ashin Garudhamma places focus on the different kinds of mind and matter that arise according to the individual mind moments in the mind process (vithi). I thank Min M. Hlaing for pointing this out.

Charts are an important pedagogical tool that monks have developed over the years. The Mula Pathan (Mūla Patthāna) Sayadaw originally developed and taught with such charts starting in the 1940s, and today charts continue to be widely used when teaching the Abhidhamma. (see Kyaw 2014, p. 159). Informal conversation (18 May 2018), Fremont, California. Interview (11 April 2021), internet communication. Fieldnotes (15 December 2014), Kanmon, Myanmar. Interview Ma Aye Myint (21 August 2018), Sagaing, Myanmar. Ashin Nyanawara explained that, "'Silence' in front of an esteemed teacher/master/senior-monk is a 'sign of respect'in Buddhist tradition. While the Buddha gave a Dhamma-talk to an 
audience, there were hundreds, on some occasions thousands of monks as well as lay persons. There, nobody spoke, coughed, or even sneezed." Email communication (25 December 2021).

Repeated ordination or renewed ordination (Burmese: kan htat [kam thap]) has various benefits. It is an additional ordination for a monk that can be a way to ensure proper ordination and/or to accumulate merit. In addition, it allows a monk to request items from sponsors, since monks are not normally allowed to ask for things verbally, but are allowed to ask their honorary parents. Nonetheless, repeated or renewed ordination can make disrobing for a monk more difficult, since there are more responsibilties associated with honorary parents. Honorary parents do not have to be older than the monk. They also do not have to continue their patronage, the ordination can be a one time donation event.

Interview, Daw Yan Po (15 April 2021), internet communication. Daw Yan Po described her background as half Bamar (mother) and half Chinese (father), but she explained that she never went to Chinese temples in her youth. Her daughter (in her twenties) explained that she became interested in learning Abhidhamma from seeing her mother study, and so accompanied her to the monastery in Fremont. She was interested in the first chapters, but seemed to enjoy her time volunteering at meditation retreats, donation events, and learning about the Buddha's biography more than studying Abhidhamma.

While to "express one's gratitude" or "return the kindness" may be more familiar expressions, this expression of "returning the gratitude" I had heard in English and seems to place more emphasis on the aspects of return or repay. The Universal Burmese-English-Pali Dictionary (Hoke Sein 1980) defines kyezusat (kyeh jūh chap) as one who "gives a service in return" or "requites a favour". I thank Ashin Nyanawara for pointing this out.

32 See Carbine (2011) for more on the importance of the sāsana being maintained and upheld collectively by the laity, monks, and nuns. Insein Sayadaw is one of the most famous and influential monks currently residing in Myanmar. Interview, Ma Wizzethi (23 July 2017), Sagaing, Myanmar. Interview, Dhamma teacher (2 May 2014), Fremont, California. Interview (15 April 2021).

\section{References}

Anuruddha, Ācariya, and Bhikkhu Bodhi. 2000. A Comprehensive Manual of Abhidhamma: The Abhidhammattha Sangaha of Ācariya Anuruddha. Edited by Bhikkhu Bodhi. Seattle: BPS Pariyatti Editions.

Bao, Jiemin. 2008. Thai Americans: Performing Gender. In Emerging Voices: Experiences of Underrepresented Asian Americans. New Brunswick: Rutgers University Press, pp. 145-59.

Barth, Fredrik. 2002. An Anthropology of Knowledge. Current Anthropology 43: 1-18. [CrossRef]

Bode, Mabel. 1909. The Pali Literature of Burma. London: Royal Asiatic Society.

Braun, Erik. 2013. The Birth of Insight Meditation: Meditation, Modern Buddhism, and the Burmese Monk Ledi Sayadaw. Chicago: University of Chicago Press. [CrossRef]

Carbine, Jason. 2011. Sons of the Buddha: Continuities and Ruptures in a Burmese Monastic Tradition. Berlin and New York: Walter De Gruyter GmbH \& Co. [CrossRef]

Cheah, Joseph. 2011. Race and Religion in American Buddhism: White Supremacy and Immigrant Adaptation. New York: Oxford University Press. [CrossRef]

Harriden, Jessica. 2012. The Authority of Influence: Women and Power in Burmese History. Copenhagen: NIAS Press.

Ho, Tamara C. 2008. Women of the Temple: Burmese Immigrants, Gender, and Buddhism in a U.S. Frame. In Emerging Voices: Experiences of Underrepresented Asian Americans. Edited by Huping Ling. New Brunswick: Rutgers University Press, pp. 183-98.

Hoke Sein, U. 1980. kyeh jūh chap. In The Universal Burmese-English-Pali Dictionary, 1st ed. Rangoon: U Hoke Sein.

Ikeya, Chie. 2011. Refiguring Women, Colonialism, and Modernity in Burma. Honolulu: University of Hawai'i Press.

Jordt, Ingrid. 2005. Women's Practices of Renunciation in the Age of Sāsana Revival. In Burma at the Turn of the Twenty-First Century. Edited by Monique Skidmore. Honolulu: University of Hawai'i Press, pp. 41-64.

Jordt, Ingrid. 2006. Defining a True Buddhist: Meditation and Knowledge Formation in Burma. Ethnology 45: 193-207. [CrossRef] Jordt, Ingrid. 2007. Burma's Mass Lay Meditation Movement: Buddhism and the Cultural Construction of Power. Athens: Ohio University Research in International Studies.

Kawanami, Hiroko. 2013. Renunciation and Empowerment of Buddhist Nuns in Myanmar-Burma: Building a Community of Female Faithful. Leiden. Boston: Brill.

Kawanami, Hiroko. 2020. The Culture of Giving in Myanmar: Buddhist Offerings, Reciprocity and Interdependence. New York: Bloomsbury Publishing.

Kyaw, Pyi Phyo. 2014. Pațhāna (Conditional Relations) in Burmese Buddhism. Ph.D. dissertation, King's College, London, UK.

Ledi Sayadaw. 1986. Paramatthasamkhip Kyamh. Yangon: Ministry of Religious Affairs. First Published 1904.

Ledi Sayadaw. n.d. Paramatthasamkhip Lak Cvai. Edited by Ledi Pandita (U Maung Gyi). Yangon: Ledi Maṇduin.

Nārada, U. 1969. Conditional Relations (Pațthāna): Being Vol. 1 of the Chațthasangāyana Text of the Seventh Book of the Abhidhamma Pițaka. London: The Pali Text Society.

Paññasāmi, and Mabel Bode. 1897. Sāsanavaṃsa. Edited by Mabel Bode. London: Pali Text Society. 
Rawe Htun. 2001. The Modern Buddhist Nun. Translated by San Lwin. Yangon: U Tin Shein.

Roberts, Jayde Lin. 2016. Mapping Chinese Rangoon: Place and Nation among the Sino-Burmese. Seattle/London: University of Washington Press.

Saruya, Rachelle. 2020. Directions of Learning, Learning Directions: Myanmar-Burmese Buddhist Nuns, Responsibility, and Their Experiences with the Scriptural Examinations. Buddhist Studies Review 37: 151-74. [CrossRef]

Starling, Jessica. 2018. Audience, Authorship and Agency: Religious Educational Materials for Buddhist Women's Groups in Japan, 1900-1933. Unpublished manuscript.

Than Tun, U. 1956. History of Buddhism in Burma. Ph.D. dissertation, University of London, London, UK.

Tin Lwin. 1961. A Study of Pali-Burmese Nissaya with Special Reference to the Mahāparinibbāna-Sutta. Master's thesis, SOAS, University of London, London, UK.

Turner, Alicia Marie. 2014. Saving Buddhism: The Impermanence of Religion in Colonial Burma. Honolulu: University of Hawai'i Press. 